\title{
DEVELOPMENT OF INFORMATION LITERACY USING SELECTED EDITORS AND MATHML LANGUAGE IN EDUCATING PERSONS WITH VISUAL IMPAIRMENT
}

\section{Vojtech REGEC}

\begin{abstract}
The aim of the paper is to present the specifics of utilization of the BlindMoose editor, Lambda editor and MathML language in the context of developing information literacy when educating integrated pupils with visual impairment at secondary schools in the Czech Republic. Within our research, on the sample of employees from eleven special education centres for visually impaired persons, we have monitored their level of awareness of the editors and MathML language. We found out that the problem in practice consists in unsatisfactory general knowledge regarding these editors as well as insufficient practical experience in their utilization in education process among the staff of special education centres working with visually impaired clients as well as among the secondary school teachers. At the same time, we have examined whether in addition to mathematics and technical subjects, the rate of information literacy also determines broader aspects of socialization of the persons with visual impairment.
\end{abstract}

Key words: BlindMoose editor, Lambda editor, information literacy, MathML language, education, visual impairment.

\section{ROZVOJ INFORMAČNEJ GRAMOTNOSTI VYUŽITÍM VYBRANÝCH EDITOROV A JAZYKA MATHML VO VZDELÁVANÍ ZRAKOVO POSTIHNUTÝCH}

Resumé: Ciel'om príspevku je prezentovat' špecifiká využitia editora BlindMoose, editora Lambda a jazyka MathML v kontexte rozvoja informačnej gramotnosti vo vzdelávaní integrovaných žiakov so zrakovým postihnutých na stredných školách v Českej republike. V rámci realizovaného výskumu sme na vzorke pracovníkov z jedenástich špeciálnopedagogických centier pre zrakovo postihnutých sledovali, aká je ich informovanost' o editoroch a jazyku MathML. Zistili sme, že problémom praxe sú neuspokojivé znalosti pracovníkoch špeciálnopedagogických centier pre zrakovo postihnutých a učitel'ov zo stredných škôl o celkovom prehl'ade týchto editorov ako aj nedostatočné praktické skúsenosti voblasti ich využitia vo vzdelávaní. Taktiež sme zist'ovali, či miera informačnej gramotnosti determinuje okrem vyučovania matematiky a technických predmetov aj širšie aspekty socializácie zrakovo postihnutých.

Klićcová slova: editor BlindMoose, editor Lambda, informačná gramotnost', jazyk MathML, vzdelávanie, zrakové postihnutie.

\section{1 Úvod}

Prístup jednotlivcov so zrakovým postihnutím $\mathrm{k}$ informáciám $\mathrm{v}$ edukačnom procese bol v minulosti výrazne obmedzený. Rozvoj informačných technológií v súčasnosti významne ovplyvňuje celý proces sprístupňovania informácií a tiež otvára nové možnosti transformácie dát do prístupnej formy. V mnohých prípadoch odstránil tradičné prekážky, avšak v celej rade d'alších vytvoril prekážky nové. (Mendelová, Lecký, 2008) Napriek dynamickému rozvoju informačných technológií aj nad'alej platí tvrdenie, že ešte aj $\mathrm{v}$ súčasnosti nie je prístup $\mathrm{k}$ informáciám u vidiacich a nevidiacich rovnocenný. Obzvlášt' sa tento jav ukazuje pri technických informáciách, kde bežne používané technológie na transformáciu textu do digitálnej formy nie sú vždy automaticky schopné sprístupnit' informácie, ktoré obsahujú množstvo špecifických symbolov a formátov.

$\mathrm{Z}$ aspektu podpory a rozvoja informačnej gramotnosti u zrakovo postihnutých je klúčové sledovat' vhodnost' a koncept nastavených prostriedkov vo vzdelávaní. Úroveň informačnej gramotnosti jednotlivca so zrakovým postihnutím 
v oblasti zapisovania matematických a iných technických výrazov je determinovaná spôsobom využitia ICT v podmienkach vzdelávania.

Glozar a kol. (2007) poukazujú na niekol'ko možností, ako prostredníctvom špeciálnych nástrojov môžeme tvorbu matematických zápisov realizovat' $\mathrm{v}$ elektronickej forme. Medzi najpoužívanejšie nástroje patrí predovšetkým editor Lambda, InftyEditor ako aj systém Duxbury Braille Translator. K d'alším možnostiam zápisu matematiky patrí tiež využitie programovej nadstavby (rozšírení, doplnkov) $\mathrm{v}$ rámci už vytvorených programov. $\mathrm{K}$ takýmto možnostiam patrí napríklad editor Blindmoose a Math Type pre platformu Microsoft Office Word, odt2braille (platforma OpenOffice Writer) ako aj jazyk MathML spracovávaný $\mathrm{v}$ rámci platformy DAISY (MathML-in-DAISY).

Limitom viacerých nástrojov zo zahraničia $\mathrm{v}$ porovnaní napríklad s českým editorom Blindmoose je skutočnost', že nemajú implementovanú českú Braillovskú normu. Naopak, ich obrovskou výhodou je lepšia možnost' konverzie dát, vyššia podpora pri práci s matematickými výrazmi, väčšia podpora matematických symbolov a d'alšie. V nasledujúcich podkapitolách budeme venovat' pozornost' dvom vybraným matematickým editorom, ktoré v Českej republike patria v praxi medzi najčastejšie používané. Okrem týchto editorov budú uvedené základné aspekty jazyka MathML a hlavné zistenia $\mathrm{z}$ oblasti informačnej gramotnosti pracovníkov školských poradenských centier pre zrakovo postihnutých o možnostiach využitia špeciálnych nástrojov k zápisu matematických výrazov.

\section{Editor BlindMoose}

Editor BlindMoose (v súčasnosti vo verzii 2 BlindMoose 2) bol vytvorený na Masarykovej univerzite $\mathrm{v}$ spolupráci so strediskom Teiresiás v roku 2004. Pôvodne tento nástroj vychádza z dvoch bakalárskych prác, ktorých autormi sú Jan Boček a Martin Endl. (Glozar a kol., 2007)

BlindMoose umožnil ako prvý v Českej republike štandardný zápis matematiky podl'a českej národnej šest'bodovej normy z roku 1996. Tento nástroj funguje ako sada makier $\mathrm{v}$ rámci textového editora Microsoft Office Word. Výhodou týchto makier, je možnost' vytvárat' a editovat' základné matematické texty nevidiacim aj vidiacim používatel'om. Nevýhodou editora je absencia automatickej konverzie $\mathrm{z}$ externého formátu, ako je TeX alebo MathML. (Glozar a kol. 2007) Z uvedeného dôvodu súhlasíme s tvrdením Šimeka (2008), ktorý uvádza, že použitie editora BlindMoose nie je ani v prostredí základných a stredných škôl vždy plne uspokojivé, pretože nároky na softvér $\mathrm{k}$ plnohodnotnej práci s matematickými zápismi v elektronickej forme môžu byt' v niektorých prípadoch ovel'a vyššie.

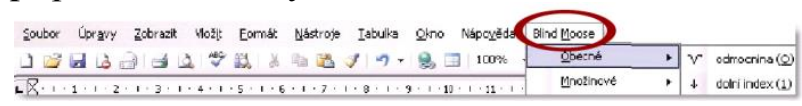

Obr 1: Zobrazenie novej položky „Blind Moose“ $v$ hlavnej ponuke (menu) textového editora $M S$ Word 2003

\section{Editor Lambda}

Pojem Lambda predstavuje matematický editor, ktorý má v sebe implementovaný lineárny Lambda kód, a tým umožňuje nevidiacim čítanie, úpravu a tvorbu matematických výrazov. Spôsob zápisu bol vyvinutý v rámci projektu s názvom Linear Access to Mathematics for Braille Device and Audio Synthesis. Horňanský (2009) uvádza, že Lambda kód je konvertovatel'ný na vstupe aj na výstupe do MathML, a teda je nepriamo konvertovatel'ný aj so zápisom LaTeX, čo nevidiacim $\mathrm{v}$ súčasnosti umožňuje prístup $\mathrm{k}$ väčšine technických dokumentov. Lambda kód je štruktúrovaný kompaktným spôsobom, ktorý vidiacemu aj nevidiacemu používatel'ovi editora Lambda umožňuje jednoducho pracovat' $\mathrm{s}$ výrazmi $\mathrm{v}$ n̆om vytvorenými (resp. upravovanými) aj $\mathrm{v}$ spolupráci s Braillovským displejom.

Nad značkovacím jazykom MathML funguje samotný editor (obrázok 2), ktorý dokument v kóde Lambda zobrazuje vo vybranej osembodovej norme. Vd'aka tomuto riešeniu sa podarilo prekonat' najväčší nedostatok existujúcich notácií, resp. ich vzájomnú nekompatibilitu. (Šimek, 2008)

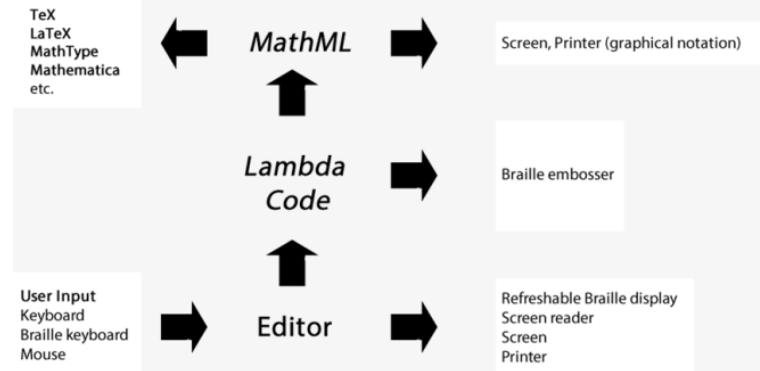

Obr 2: Znázornenie štruktúry systému Lambda (upravné podl'a Hegr, Peñáz, Sklenák In Šimek, 2008)

Podl'a Jaškovej (2008, s. 93) je program Lambda ,výbornou pomôckou pre nevidiacich študentov študujúcich integrovane. Bežní učitelia matematiky majú problémy pri vysvetl'ovaní 
učiva pre nevidiacich, pretože Braillovský matematický zápis, ktorý používajú nevidiaci, je úplne iný ako ten, ktorý používajú vidiaci. Práve program Lambda ponúka vyhovujúce riešenie pre nevidiacich žiakov, aj pre vidiacich učitel'ov a žiakov".

Editor Lambda umožňuje automatiky rozlišovat' jednotlivé bloky matematického vzorca a poskytuje prostriedky, ktoré umožňuje používatel'om postupné rozkrývanie alebo skrývanie. Práve prostredníctvom funkcie rozkrývania a skrývania vybraných častí matematického zápisu môžu nevidiaci porozumiet' vnútornú štruktúru vzorca ovel’a rýchlejšie a samotná úprava vzorca je presnejšia. Medzi d'alšie funkcie editora Lambda patrí napríklad schopnost' rozšírit' aktuálny výber na celý logický blok, automatické doplňovanie značiek ako prevencia $\mathrm{v}$ tvorbe chýb pri písaní výrazov, funkcia kopírovania posledného riadku s eliminovaním prebytočných medzier ai. Editor tiež obsahuje zabudovaný kalkulátor ako aj prostredie pre prácu s maticami (Šimek, 2008).

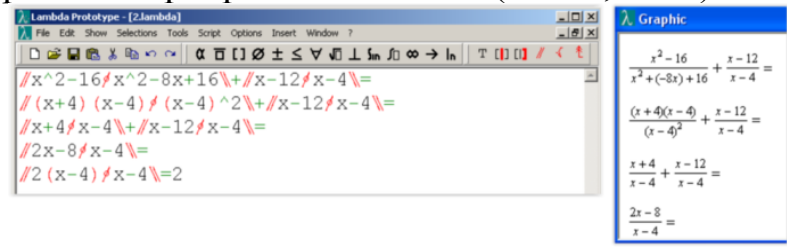

Obr 3: Hlavné okno s rozpisaným príkladom v lineárnom Lambda kóde a podokno zobrazujúce priklad $v$ štandardnom vizuálnom tvare (Horňanský, 2009, s. 46)

\section{Jazyk MathML}

Jazyk MathML (Mathematical Markup Language) predstavuje d'alší spôsob ako možno $\mathrm{v}$ lineárnej forme zapisovat' elektronicky matematické výrazy. Spôsob zápisu a syntax MathML je založený na jazyku XML (EXtensible Markup Language) a oficiálne schválený konzorciom W3 (Horňanský, 2009).

MathML bol špeciálne vytvorený pre potreby zápisu matematických notácií a následnej prezentácie na webových stránkach ako aj v d'alších typoch elektronických dokumentoch. V roku 2014 bola v druhom vydaní publikovaná jeho tretia verzia. Špecifikácia MathML 3.0 je dostupná na adrese http://www.w3.org/TR/ MathML3/.

Príklad znázornenia jednoduchého zlomku v MathML vo webovom prehliadači Mozilla Firefox uvádzame na nasledujúcom obrázku 4.
(2) Zlomok - Mozilla Firefor

Śćbor Ụpravit Zobrazil História Zálonžky Nástroje Pomocnik

$$
x=\frac{3+y}{2}
$$

Obr 4: Zobrazenie matematického vzorca vo webovom prehliadači

Na obrázku 5 uvádzame k vyššie uvedenému príkladu jeho zdrojový kód.

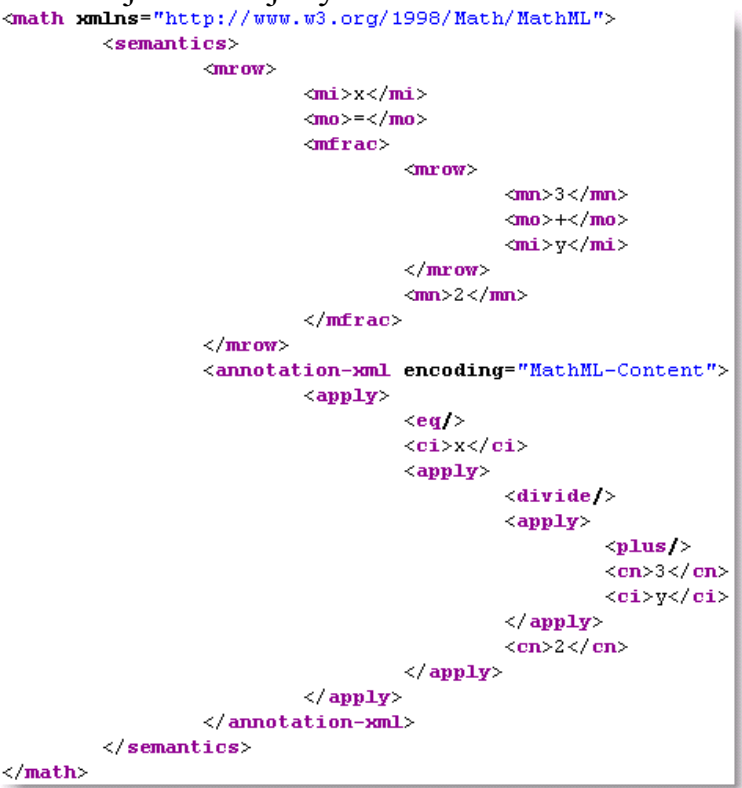

Obr 5: Zobrazenie stavby (syntax) zdrojového kódu v MathML (pre zlomok na obrázku 4)

Súhlasíme s tvrdením Šimeka (2009), ktorý v tejto súvislosti hovorí, že výsledný kód je rozsiahly a jeho priame editovanie je príliš náročné. Ako d’alej citovaný autor (tamtiež) výstižne uvádza, najvhodnejším riešením sa ukazuje využívat' MathML ako vnútorný kód, nad ktorým bude fungovat' ako nadstavba editor (napríklad Lambda), ktorý nevidiacemu obsah dokumentu interpretuje, podobne ako už existujúce nástroje, ktoré zdrojový kód MathML prevádzajú do vizuálnej podoby.

\section{Východiská výskumu}

Ciel'om výskumu bolo zistit', aká je informačná gramotnost' pracovníkov školských poradenských centier pre zrakovo postihnutých o možnostiach editorov a jazyka MathML k zápisu matematických výrazov. Pracovníci školských poradenských centier majú kl'účový význam voblasti vzdelávania žiakov so zrakovým postihnutím $\mathrm{v}$ inkluzívnych podmienkach, pretože poskytujú školám informačné, diagnostické, metodické a poradenské služby. 
V rámci výskumu sme oslovili celý základný súbor (14 špeciálne pedagogických centier pre zrakovo postihnutých) v Českej republike, pričom so zapojením do výskumu súhlasili poradenskí pracovníci z 11-tich centier. Zber dát prebiehal formou interview a bol realizovaný $\mathrm{v}$ roku 2010

\section{Výsledky výskumu}

V oblasti využitia moderných technológií pri sprístupňovaní matematických zápisov a ich linearizácie v elektronickej forme sme zist'ovali, aké informácie poskytujú školám pracovníci školských poradenských centier. Väčšina pracovníkov (73\%) uviedla, že nepozná žiadne špeciálne programy (napr. editor Lambda a pod.) ako aj jazyk MathML $\mathrm{k}$ tomuto účelu. Neuspokojivé boli aj znalosti poradenských pracovníkov o možnostiach využitia osembodového zápisu, a to aj napriek tomu, že všetci oslovení pracovníci mali prehl'ad o šest'bodovej norme. Na základe týchto zistení tak môžeme konštatovat', že poradenskí pracovníci v praxi prehliadajú nové možnosti, ako efektívne zapisovat' $\mathrm{v}$ elektronickej forme matematické zápisy a tým nepriaznivo determinujú rozvoj informačnej gramotnosti žiakov so zrakovým postihnutím.

Zo získaných výsledkov vyplýva, že špeciálny matematický editor vhodný na lineárny zápis matematických, prípadne iných technických výrazov poznali celkovo iba traja respondenti (27\%), pričom iba jeden poradenský pracovník $(10 \%)$ má s jeho využitím praktické skúsenosti. $\mathrm{K}$ týmto zisteniam citujeme alarmujúcu výpoved' jedného respondenta, ktorý poukazoval na prístup učitel'a matematiky pri vyučovaní nevidiaceho študenta v inkluzívnych podmienkach.

„Středoškolšti učitelé jaksi u integrovaných nevidomých žáků se nechtěji učit tady tyhle ty věci jako editor Lambda a podobně. Vètšinou se to pak obcházi jakousi modifikaci učiva. Takže ten zrakově postižený se uči jenom to, co sám jakoby zvládl a do těch těššich věcí se nepouští."

Viacero pracovníkov nám hovorilo aj o negatívnom dopade nedostatočných znalostí u učitel'ov o možnostiach zápisu matematiky u nevidiacich študentov (obrázok 6). Zmienený negatívny dopad sa napríklad premietal do vytvárania vlastného spôsobu zápisu matematických, či iných technických výrazov, ktorý vznikol na základe dohody medzi učitel’om a žiakom so zrakovým postihnutím. Obrovským nedostatkom uvedeného postupu je nekompatibilita týchto individuálnych druhov zápisu, napríklad pri d’alšom štúdiu, ako aj zbytočné redukovanie učebnej látky.

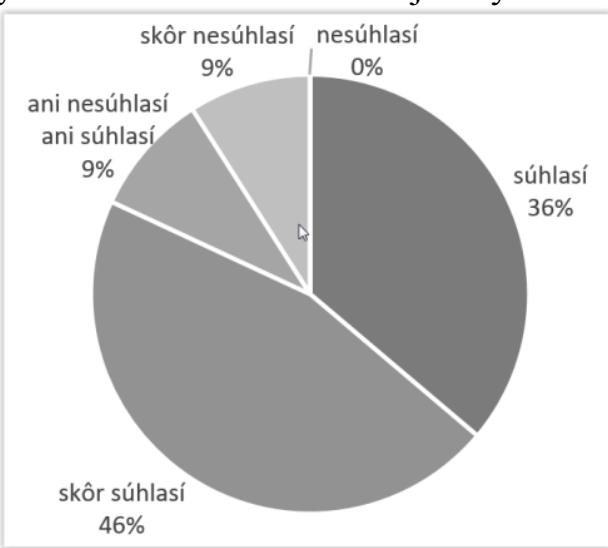

Obr 6: Miera súhlasu pracovníkov školských poradenských centier s negatívnym vplyvom na informačnú gramotnost' u žiaka so zrakovým postihnutim zdôvodu nedostatočných znalostí a praktických skúseností učitel'ov o možnostiach využivania matematických editoroch

Kvalita vyučovania matematiky a technických predmetov determinuje $\mathrm{v}$ rôznej intenzite aj d'alšie aspekty socializácie. Podl'a respondentov sa najčastejšie jedná o nerovný prístup ku vzdelaniu (82\%) a osvojovaniu si limitovaných kompetencií $\mathrm{v}$ práci s matematickými výrazmi. Pozornost' je tiež potrebné venovat' aj vplyvu na výber vysokej školy a vol'by povolania. Jednotlivé zistenia ilustrujeme na nasledujúcom obrázku 7 .

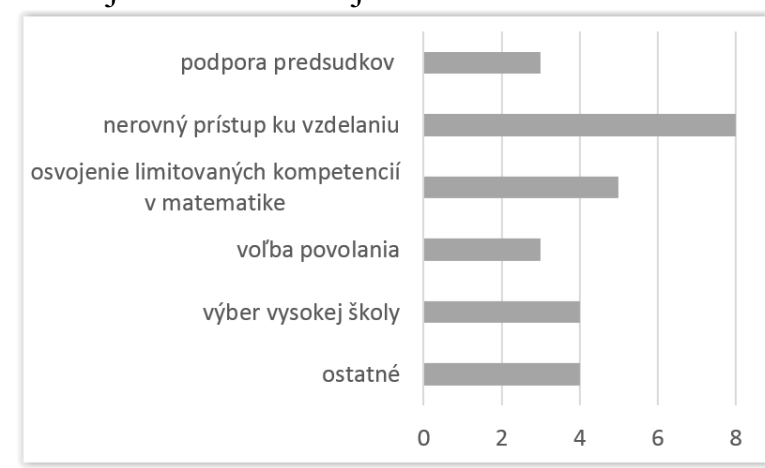

Obr 7: Vplyv kvality vyučovania matematiky na vybrané oblasti

$\mathrm{V}$ rámci výskumu sme sa $\mathrm{v}$ súvislosti so zistenými nedostatočnými znalost’ami učitel’ov o možnostiach využitia matematických zápisov $\mathrm{v}$ elektronickej forme zist'ovali aj pravdepodobné príčiny, ktoré vplývajú na úroveň týchto znalostí. Pracovníci školských poradenských centier najčastejšie poukazovali na nedostatočnú pregraduálnu prípravu učitel'ov $\mathrm{v}$ inkluzívnom prostredí (63\%), nedostatočnú metodickú podporu poradenských pracovísk (46\%) ako aj na nedostatočný prístup a časové možnosti učitel'ov ku ich d’alšiemu vzdelávaniu (27\%). 


\section{Záver}

$\mathrm{Na}$ základe výsledkov prezentovaného výskumu môžeme konštatovat', že $\mathrm{v}$ integrovanom vzdelávaní je problematika informačnej gramotnosti žiakov so zrakovým postihnutím aktuálnym problémom praxe. Dôležité je poukázat' na rozpor medzi teóriou a praxou voblasti možností prístupu $\mathrm{k}$ informáciám $\mathrm{v}$ rámci elektronickej formy lineárneho zápisu matematiky prostredníctvom špeciálnych nástrojov. Školskí poradenskí pracovníci ako aj učitelia na stredných školách nemajú dostatočné znalosti o týchto editoroch, vrátane jazyka MathML, a častokrát tak pristupujú $\mathrm{k}$ menej efektívnym technikám vyučovania. $\mathrm{Na}$ podobný problém $\mathrm{v}$ oblasti edukácie dlhodobo poukazuje aj Peňáz (2002), ked' hovorí o vypúšstaní učebnej látky, ktorá sa viaže na zrak a vychádza práve $\mathrm{z}$ nesprávne interpretovanej špeciálnopedagogickej tézy o individuálnom prístupe.

Odborné metodické vedenie školských pracovníkov (učitel', asistent pedagóga, špeciálny pedagóg) je tak nevyhnutným predpokladom k zvyšovaniu informačnej gramotnosti študentov so zrakovým postihnutím $\mathrm{v}$ inkluzívnych podmienkach $\mathrm{v}$ oblasti vyučovania matematiky ako aj iných technicky orientovaných predmetov.

\section{Literatura}

[1] GLOZAR, J. ET AL. Přistupnost e-learningu pro studenty s postižením. 2007. 15 s. Brno: Středisko pro pomoc studentům se specifickými nároky Masarykova univerzita.

[2] HORŇANSKÝ, M. Sprístupňovanie matematiky nevidiacim na Slovensku prostrednictvom editora Lambda. 2009. 86 s. Bratislava: Univerzita Komenského.

[3] JAŠKOVÁ, L. Digitálne technológie vo vzdelávani zrakovo postihnutých. 2008. 158 s. Bratislava: Univerzita Komenského.
[4] MENDELOVÁ, E.; LECKÝ, P. Prístupné študijné zdroje pre nevidiacich študentov. In: Niektoré technologické inovácie $v$ špeciálnej pedagogike. Levoča: Matej Hrebenda Slovak Library for the Blind in Levoča. Ročník 38. Číslo 7. 2008. s. 54-65. ISSN 1335-6100.

[5] PEŇÁZ, P. Gramotnost nevidomých a perspektivy hmatového kódování informací. In Jesenský, J. Edukace a rehabilitace zrakově postižených na prahu nového milénia. 2002. s 256-268. Hradec Králové: Gaudeamus, ISBN 807041-041-8.

[6] REGEC, V. Praktické využitie informačných a komunikačných technológii $u$ žiakov so zrakovým postihnutim. Olomouc: Univerzita Palackého v Olomouci, 2010. 244 s. [Dizertačná práca. ]

[7] REGEC, V. E-Exclusion and E-Inclusion of Students with Visual Impairment at Secondary Schools and Universities in the Slovak Republic. In INTED2014 Proceedings. Valencia: 8th International Technology, Education and Development Conference. 2014. s. 2632-2636. ISBN: 978-84-616-8412-0.

[8] ŠIMEK, R. Matematika pro nevidomé. Počitačová podpora výuky a návrh české osmibodové normy. 2008. 79 s. Brno: Masarykova Univerzita.

PhDr. Vojtech Regec, Ph.D.

Ústav speciálněpedagogických studií

Pedagogická fakulta UP

Žižkovo nám. č. 5

771 40, Olomouc, ČR

Tel: 00420585635323

E-mail: vojtech.regec@upol.cz

Www pracoviště: www.uss.upol.cz 